\title{
Genetic Evaluation of Iraqi Awassi Rams According to Some Growth Traits of Their Progeny Lambs
}

\author{
Firas R. Al-Samarai ${ }^{1}$, Fatten A. Mohammed $^{2}$, Falah H. Al-Zaydi ${ }^{2}$, Nasr N. Al-Anbari ${ }^{3}$, \\ Yehya K. Abdulrahman ${ }^{1}$ \\ ${ }^{1}$ Department of Veterinary, Public Health, College of Veterinary Medicine, University of Baghdad, Baghdad, Iraq \\ ${ }^{2}$ Department of Animal Resources, Directorate of Baghdad Agriculture, Ministry of Agriculture, Baghdad, Iraq \\ ${ }^{3}$ Department of Animal Resources, College of Agriculture, University of Baghdad, Baghdad, Iraq

\section{Email address:} \\ firas_rashad@yahoo.com (F. R. Al-Samarai), fatten_2000@yahoo.com (F. A. Mohammed), falah_vet@yahoo.com (F. H. Al-Zaidi), \\ nasr_noori@yahoo.com (N. N. Al-Anbari), yehyeabdulrahman@yahoo.com (Y. K. Abdulrahman)
}

\section{To cite this article:}

Firas R. Al-Samarai, Fatten A. Mohammed, Falah H. Al-Zaydi, Nasr N. Al-Anbari, Yehya K. Abdulrahman. Genetic Evaluation of Iraqi Awassi Rams for Some Growth Traits of Their Lambs. American Journal of Applied Scientific Research. Vol. 2, No. 1, 2016 , pp. 1-5. doi: 10.11648/j.ajasr.20160201.11

\begin{abstract}
This study was carried out on the research station of sheep and goat (Abo Gharib, west of Baghdad, Iraq) to evaluate the 120 Awassi rams for the birth weight (BW), weight at weaning (WW) and pre-weaning daily gains (DG) of their lambs after adjusting to the effects of parity, year of birth, sex, and type of birth (single, twin). Restricted Maximum Likelihood (REML) method in a mixed model (paternal half sib) was utilized to estimate the heritability $\left(\mathrm{h}^{2}\right)$ for above mentioned traits. Proc mixed in SAS program was used to estimate Best Linear Unbiased Prediction (BLUP) values of rams for the three studied traits. The results revealed that the means of BW, WW and DG were 3.85, 26.64 and $0.181 \mathrm{~kg}$ respectively. The studied traits were significantly $(\mathrm{P}<0.01)$ affected by all fixed effects except the effect of ram on WW and DG which was significant $(\mathrm{P}<$ 0.05). Heritability estimates $\left(\mathrm{h}^{2}\right)$ of BW, WW and DG were $0.23,0.12$ and 0.19 respectively. The lowest and highest BLUP values for the mentioned traits were $-0.325,0.255 \mathrm{~kg},-1.142,1.284 \mathrm{~kg}$, and $-0.103,0.053 \mathrm{~kg}$ respectively. In conclusion: the results indicated that selection of rams for DG and BW could play an important role for improving the growth traits of Awassi sheep due to the high range among BLUP values along with the acceptable estimations of heritability.
\end{abstract}

Keywords: Awassi Lamb, Birth Weight, Weaning Weight, Heritability

\section{Introduction}

Sheep husbandry in Iraq has been a historically important component of rural development and still fulfills a sustainable role in the livelihood of farmers. The country has a tradition of the consumption of sheep products, especially lamb and mutton. The native sheep breeds in Iraq include the Karadi (Kurdi, Hamdani, Jaff and Dzaie) 20\%, Awassi (Naami and Shefali) 58.2\% and Arabi 21.8\% (Al-Barzinji and Othman, 2013). The Awassi sheep breed has been introduced into many countries, and have been shown to have superior performance to some native breeds (Todorovski, 1988). This breed was widespread because of its good characteristics in regards to meat price and quality (Kingwell et al., 1995), milk quality (Sunderman and Johns, 1994), validity of wool for the carpet industry (Lightfoot, 1988), and its ability to cope stress of high environmental temperature (AbiSaab and Sleiman, 1995). Unfortunately, the Awassi has taken its place among the genotypes of indigenous genetic resources requiring a protection project due to their declining numbers (Üstüner and Oğan, 2013).

Today on sheep farming, a large part of the economic income is based on meat production. Consequently, it is observed that studies aimed to increase lambs productivity and growth performance in lambs, which are the main source of meat production, have intensified (Özcan et al., 2001).

In order to devise effective breeding plans for genetic improvement of Awassi sheep, information on the extent of genetic and environmental factors on performance traits is the pre-requisite. Therefore; this study was planned to generate information on the relative importance of genetic and environmental factors on the growth performance of Awassi sheep in addition to estimate the heritability and Best Linear Unbiased Prediction (BLUP) for some growth traits. 


\section{Material and Methods}

In this study, records of Awassi lambs bred at the research station of sheep and goats (Abu Gharib, west of Baghdad, Iraq) were utilized over three years $(2007-2009)$. Data included 1318 birth weight (BW), 821 weaning weight (WW) and 821 pre-weaning daily gain (DG) records. The numbers of ewes and rams were 849 and 120 respectively.

Restricted Maximum Likelihood (REML) method in a mixed model (paternal half sib) was used to estimate the heritability $\left(\mathrm{h}^{2}\right)$ for mentioned traits. The general statistical model included fixed effects due to parity, sex, year of birth, month of birth, type of birth and age at weaning as covariate.

Proc mixed in SAS program (2010) was used to estimate Best Linear Unbiased Prediction (BLUP) values of rams for all studied traits.

SAS program Ver. 9.1 was used for data analysis. Two
Mathematical models were assumed as shown below:

Model I for BW.

Yijklmno $=\mu+\mathrm{Pi}+\mathrm{Yj}+\mathrm{Sk}+\mathrm{Tl}+\mathrm{Mm}+\mathrm{F}_{\mathrm{n}}+$ eijklmno.

Where; $\mathrm{Y}_{\mathrm{ijklm}}=$ Birth weight; $\mu=$ Population mean; $\mathrm{Pi}=$ Effect of parity (1-3); Yj = Year of birth, 2007, 2008, 2009; $\mathrm{Sk}=$ Sex, Male, female; $\mathrm{Tl}=$ Type of birth (Single, twin); $\mathrm{Mm}=$ Month of birth (January, February, and March); eijklmno $=$ random error associated with each observation. It is assumed to be normally distributed with mean zero and variance $\sigma^{2}$.

Model II for WW and DG.

As weaning lambs in this station depend on weight rather than age, the WW and DG were adjusted for age at weaning.

Yijklmno $=\mu+\mathrm{Pi}+\mathrm{Yj}+\mathrm{Sk}+\mathrm{Tl}+\mathrm{Mm}+\mathrm{Fn}+\mathrm{b}(\mathrm{Xijklmn})$ + eijklmno.

The notation of the second model is similar to the first model except $\mathrm{b}=$ regression coefficient; Xijklmn = Age of lamb at weaning.

Table 1. Lease square means $\pm S E(\mathrm{~kg})$ for birth weight $(B W)(\mathrm{kg})$, weaning weight $(W W)$ and daily gain $(D G)$ in Awassi lambs.

\begin{tabular}{llllll}
\hline Sources of variation & No. of records & BW Mean \pm SE & No. of records & WW Mean \pm SE & DG Mean \pm SE \\
\hline Parity & & & & & \\
$1^{\text {st }}$ & 549 & $3.67 \pm 0.14^{\mathrm{b}}$ & 239 & $26.82 \pm 0.88^{\mathrm{a}}$ & $0.164 \pm 0.015^{\mathrm{b}}$ \\
$2^{\text {nd }}$ & 539 & $4.19 \pm 0.11^{\mathrm{a}}$ & 354 & $28.73 \pm 0.68^{\mathrm{a}}$ & $0.191 \pm 0.012^{\mathrm{a}}$ \\
$3^{\text {rd }}$ & 230 & $4.28 \pm 0.16^{\mathrm{a}}$ & 228 & $23.48 \pm 1.09^{\mathrm{b}}$ & $0.139 \pm 0.012^{\mathrm{c}}$ \\
Year of birth & & & & \\
2007 & 528 & $3.64 \pm 0.12^{\mathrm{b}}$ & 222 & $31.13 \pm 0.88^{\mathrm{a}}$ & $0.221 \pm 0.013^{\mathrm{a}}$ \\
2008 & 574 & $3.78 \pm 0.12^{\mathrm{b}}$ & 383 & $24.06 \pm 0.64^{\mathrm{b}}$ & $0.141 \pm 0.013^{\mathrm{b}}$ \\
2009 & 216 & $4.68 \pm 0.17^{\mathrm{a}}$ & 216 & $23.84 \pm 1.16^{\mathrm{c}}$ & $0.132 \pm 0.013^{\mathrm{b}}$ \\
Month of birth & & & & \\
January & 326 & $4.25 \pm 0.04^{\mathrm{a}}$ & 233 & $29.18 \pm 0.36^{\mathrm{a}}$ & $0.202 \pm 0.005^{\mathrm{a}}$ \\
February & 804 & $4.03 \pm 0.02^{\mathrm{b}}$ & 483 & $26.20 \pm 0.24^{\mathrm{b}}$ & $0.179 \pm 0.004^{\mathrm{b}}$ \\
March & 188 & $3.83 \pm 0.05^{\mathrm{c}}$ & 105 & & $0.151 \pm 0.007^{\mathrm{c}}$ \\
Type of birth & & & $23.65 \pm 0.52^{\mathrm{c}}$ & \\
Single & 676 & $4.33 \pm 0.03^{\mathrm{a}}$ & 416 & $24.21 \pm 0.29^{\mathrm{a}}$ & \\
Twin & 642 & $3.74 \pm 0.03^{\mathrm{b}}$ & 405 & & $0.189 \pm 0.004^{\mathrm{a}}$ \\
Sex & & & & $0.166 \pm 0.004^{\mathrm{b}}$ \\
Male & 653 & $4.15 \pm 0.03^{\mathrm{a}}$ & 398 & $27.77 \pm 0.31^{\mathrm{a}}$ & \\
Female & 665 & $3.92 \pm 0.03^{\mathrm{b}}$ & 423 & $24.92 \pm 0.29^{\mathrm{b}}$ & $0.189 \pm 0.004^{\mathrm{a}}$ \\
Reg. on age at weaning & & & $26.64 \pm 0.25$ & $0.166 \pm 0.003^{\mathrm{b}}$ \\
Overall mean & 1318 & $3.85 \pm 0.02$ & 821 & $0.003 \pm 0.0001^{* *}$ \\
\hline
\end{tabular}

Means of the same column with different letters differ significantly at $\mathrm{P}<0.01$.

$* *(\mathrm{P}<0.01)$

Table 2. Heritability estimates and BLUP values of birth weight, weaning weight, and pre-weaning daily gain (kg) in Iraqi Awassi rams

\begin{tabular}{|c|c|c|c|c|c|c|}
\hline & & Birth weight & & Weaning weight & & Daily gain \\
\hline Heritability & & $0.23 \pm 0.04$ & & $0.12 \pm 0.04$ & & $0.19 \pm 0.04$ \\
\hline Sequence & Sire No. & BLUP & Ram No. & BLUP & Ram No. & BLUP \\
\hline 1 & 12345 & -0.32520 & 11996. & -1.14220 & 11873. & -0.10330 \\
\hline 2 & 11920 & -0.26250 & 11877. & -0.90160 & 11877. & -0.09137 \\
\hline 3 & 11975 & -0.24560 & 11958. & -0.79060 & 11878. & -0.06243 \\
\hline 4 & 1239 & -0.15690 & 11873. & -0.76560 & 11958. & -0.03495 \\
\hline 5 & 11911 & -0.15100 & 11941. & -0.66780 & 11961. & -0.02903 \\
\hline- & & - & - & - & & \\
\hline 116 & 11916 & 0.17260 & 11948. & 0.57440 & 11914. & 0.02901 \\
\hline 117 & 11925 & 0.19210 & 11908. & 0.63980 & 11931. & 0.03187 \\
\hline 118 & 11978 & 0.19350 & 11914. & 0.77440 & 11989. & 0.03926 \\
\hline 119 & 11964 & 0.21480 & 11913. & 0.77760 & 1748. & 0.04575 \\
\hline 120 & 12241 & 0.25520 & 11989. & 1.28400 & 11913. & 0.05321 \\
\hline
\end{tabular}




\section{Results and Discussion}

Least square means \pm SE of BW, WW and DG of the Awassi lambs in relation to parity, month and year of lambing, type of birth and sex are presented in Table 1. The overall means of $\mathrm{BW}, \mathrm{WW}$ and DG were $3.85 \pm 0.02 \mathrm{~kg}$, $26.64 \pm 0.25 \mathrm{~kg}$ and $0.181 \pm 0.003 \mathrm{~kg}$ respectively.

Estimates of heritability $\left(\mathrm{h}^{2}\right)$ and BLUP values are in Table 2. The heritability of the BW, WW and DG was $0.23,0.19$ and 0.12 respectively.

The BLUP values of rams for the studied traits are shown in table 2. The lowest BLUP values for BW, WW, and DG were $-0.325,-1.142$ and $-0.103 \mathrm{~kg}$ respectively. The corresponding values of highest BLUP values were 0.225 , 1.284 , and $0.053 \mathrm{~kg}$.

The mean of the BW in current study was lower than the range of the means (4.05 to $4.52 \mathrm{~kg}$ ) reported by several researchers for Awassi lambs (Esenbuğa and Dayığlu, 2002; Hassen et al., 2004; Dikmen et al., 2007; Jawasreh and Khasawneh, 2007; Kridli et al., 2007; Tabbaa et al., 2008; Üstüner and Oğan, 2013). However, it is consistent with other estimates of $3.82,3.70$ and $3.67 \mathrm{~kg}$ reported by Al-Kass et al., (1986), Al-Wahab (2003) and Al-Khazrji et al., (2014) respectively.

The results of the current research showed that rams had significant $(\mathrm{P}<0.01)$ effect on BW. Similar results were obtained by Al-Hilali, (1982), and Alkass et al., (1991). The parity affected the BW significantly $(\mathrm{P}<0.01)$. The mean of BW increased with advancing parity and this could be attributed to increasing of ewe's weight. According to Kř́žzek et al., (1983), live weight of dams significantly affected live weight of lambs at birth. Hence, balanced feeding for dam could lead to the heavier lambs at birth (Obaido, 2010). Similar finding was reported by Ghoneim et al. (1982) and Al-Khazrji et al. (2014).

The effect of year of birth on the BW was significant $(\mathrm{P}<$ $0.01)$. This effect reflects the variation of the availability of rainfall and pastures among different years. The month of birth also influenced BW. Lambs born early in the lambing period (January and February) surpassed those born later (March). This could be attributed to variation in quantity and quality of dam's nutrition through the gestation period particularly in the last months. Similar results were reported by Khalaf et al., (2010) who found a similar significant $(\mathrm{P}<$ 0.01 ) trend where $\mathrm{BW}$ was $3.82,3.46$ and $3.24 \mathrm{~kg}$ for January, February and March respectively.

The type of birth and sex affected BW significantly $(\mathrm{P}<$ $0.01)$. The results showed that the birth weight was higher in males compared to females and in single-born lambs compared to twins. These results were in consistent with those reported by Dikmen et al., (2007). Singles and males generally had higher birth weights than twin births and females. These results confirmed the result obtained by Üstüner and Oğan (2013).

Results revealed that the mean of the WW $(26.64 \mathrm{~kg})$ was lower than means of $31.29,29.14$ and $27.75 \mathrm{~kg}$ reported by Özcan et al. (2001), Üstüner and Oğan, (2013) and Khalaf et al., (2010) respectively. On the other hand it is higher than the value of 21.54 to $24.30 \mathrm{~kg}$ reported by Al- Jalili et al., (2006), Al-Wahab, (2003), Aksakal et al., (2009) and AlSalman (2009).

WW differed significantly $(\mathrm{P}<0.01)$ among parities where it was heaviest in the $2^{\text {nd }}$ parity than those born in the $1^{\text {st }}$ and $3^{\text {rd }}$ parities.

This could be attributed to lamb growth rate, which is mainly affected by the dams' milk yield. High milking ewes' lambs grow faster as compared to the poor milkers (Obaido, 2010). This result was in agreement with results obtained by Al-Salman, (2009) and Al-Khazrji et al. (2014), but disagreed with others (Jawasreh and Khasawneh, 2007; Üstüner and Oğan, 2013);

There was a significant $(\mathrm{P}<0.01)$ decreasing in the WW a cross years of birth. Year of birth within locations generally showed highly significant effects on BW, WW, and yearling weight. Fluctuations in some environmental factors prevailed; in particularly quality and quantity of the available feed stuff could be an explanation (AKF, 2006).

The month of birth also influences WW. Lambs born early in the lambing period (January and February) will gain weight better than those born late (March) due to the accessibility to the pastures in spring season. Lambs born late will not be able to use pasture in spring because of their young age besides they may have higher exposure to internal parasites which thrive in the high temperature. Thus, their weaning and yearling weights will be lower than those lambed early (Elwakil et al., 2009).

The differences in WW between the months of lambing were attributed to the yearly variation in the rain precipitation and its effect on the density, growth and availability of pastures, forage, and other feeds. Similarly, different climates have been reported to influence milk production of ewes. This indirectly affects the growth of lambs (Shaker et al., (2002). The results achieved in this study are in congruency with Al-Salman, (2009) who found that WW of lams born in November and December had significantly $(\mathrm{P}<0.05)$ heavier WW (25.98 and $25.74 \mathrm{~kg}$ ) as compared with those born in January and February (22.63 and $20.85 \mathrm{~kg}$ ).

In the current study, the type of birth and sex affected significantly $(\mathrm{P}<0.01)$ the WW. The WW was higher in males compared to females and in single-born lambs compared to twins. Similar finding was obtained by Dikmen et al., (2007), Al-Salman (2009) and Üstüner and Oğan (2013).

The regression coefficient of $\mathrm{WW}$ on age at weaning was positive and significant $(\mathrm{P}<0.01)$. Thus, it is an important to adjusting WW for this variation in age at weaning.

The present estimate of DG $(0.181 \mathrm{~kg})$ appeared to be comparable with the corresponding estimates of Awassi lambs $(0.168$ to $0.205 \mathrm{~kg})$ reported by other researchers (AlSalman, 2009; Üstüner and Oğan, 2013; Al-Khazrji et al., 2014). 
The impact of all fixed effects on DG was significant $(\mathrm{P}<$ $0.01)$. The trend of changes in DG due to fixed effects is parallel to changes in WW. This could be attributed to the effect of the DG on WW.

Paternal half-sib heritability for BW, WW, and DG was given in Table 2. Their values were considered low to moderate. Heritability estimates of $0.10,0.19,0.18$, and 0.16 for BW of Awassi lambs were reported by Kazzal, (1973), Thrift et al., (1973), Aziz, (1977), Gursoy et al., (1995). A higher estimates of 0.29 and 0.41 for the same breed were obtained by Al-Hilali, (1982), and Alkass et al., (1991). The heritability estimate of the BW in the present study indicated that rams differed in their genetic potential.

The heritability estimate of the WW (0.12) was much lower than the estimate of the BW. This could be attributed to variation in maternal environment, mainly milk supply rather than to differences in genetic merit of the lambs. This estimate was similar to some estimations $(0.10,0.12$ and 0.10) reported by Thrift et al., (1973), Dzakumah et al. (1978) and Alkass et al., (1991).

In current work, heritability of DG (0.19) was higher than 0.12 and 0.07 reported by Al-Rawi et al., (1982) and, Kamber, (1987) for the same breed, while our estimate was lower than 0.51 reported by Alkass et al., (1991). Differences in heritability estimates among various studies for the same trait of the same breed could be due to differences in the records number used, the correction for different non-genetic factors, the model used and the methodology for estimating heritability of the trait (Abou-Bakr, 2009).

The lowest and highest BLUP values (Table 2) for the three traits were expressed as the percentages of the overall means for each trait to identify its weighted effect. The percentages of the lowest value of BW, WW, and DG were $8.4 \%, 4.2 \%$ and $56 \%$ respectively, whereas, the corresponding percentages for the highest values were $6.6 \%$, $4.8 \%$, and $29 \%$ respectively. Hence, the selection of the rams for the DG would be effective in raising this trait of Awassi lambs. However, the $\mathrm{h}^{2}$ of DG (0.19) was little lower than the $\mathrm{h}^{2}(0.23)$ of BW. The selection of the rams for the BW would be also effective as the $\mathrm{h}^{2}$ of BW was moderate. The expected genetic gain per generation under mass selection would be the product of the selection differential and heritability. On the other hand, the differences between highest and lowest percentage of BLUP values for WW was not high enough to justify selection procedures for its improvement particularly the trait has low $\mathrm{h}^{2}(0.12)$.

Results of the year of birth effects in the present study indicated that while BW generally tends to increase along with advancing years, the WW and DG tend to decrease. Despite the breeding plan implemented in this flock, management as well as the effectiveness of the breeding plan has to be considered in order to improve mutton production. In conclusion: the results indicated that selection of rams for DG and BW could play an important role for improving the growth traits of Awassi sheep due to the high range among BLUP values along with the acceptable estimations of heritability.

\section{References}

[1] AbiSaab, S., Sleiman, F. T. (1995). Physiological responses to stress of filial crosses compared to local Awassi sheep. Small Rum. Res., 16: 55-59.

[2] Abou-Bakr, S. (2009). Genetic and phenotypic trends of 305day milk yield of Holstein cows raised at commercial farm in Egypt. Egyptian J. Anim. Prod., 46: 85-92.

[3] Aga Khan Foundation (AKF). (2006). Report of the Rural Support Program Activities. Salamieh, Hama (in Arabic).

[4] Aksakal, V., Macit, M., Esenbuga, N. (2009). Effect of various ages of weaning on growth characteristics, survival rate and some body measurements of Awassi lambs. J. Anim. Vet. Adv., 8: 1624-1630.

[5] Al-Barzinji, Y. M. S., Othman, G. U. (2013). Genetic Polymorphism in $F e c B$ Gene in Iraqi Sheep Breeds Using RFLP-PCR Technique. IOSR Journal of Agriculture and Veterinary Science. 2: 46-48.

[6] Al-Hilliali, A. H. (1982). Genetic analysis of some postweaning productive characteristics in Awassi sheep. M. Sc. Thesis, Agricultural University Baghdad, Baghdad.

[7] Al- Jalili, Z. F., Al-Azzawi, W. A. R., Mohammed, Q. S. (2006). The effect of type of birth of both ewe and lambs and other factors on lamb birth and weaning weights. Egyptian J. Sheep, Goat Desert Anim. Sci., 1: 31-40.

[8] Alkass, J. E., Alrawi, A. A., Al-Hillali, A. H., Al-Tayy, H. M. A. (1986). Body weight of horne-vs-polled-sired Awassi lambs. 3rd World Congress on Genetics Applied to Livestock Production. Paper 3. http://digitalcommons.unl.edu/wcgalp/3.

[9] Alkass, J. E., Aziz, D. A., Hermiz, D. A. (1991). Genetic parameters of growth traits in Awassi sheep. Emirates J. of Agric. Sci., 3: 152-161.

[10] Al-Khazrji, W. J., Al-Samari, W. A., Ajil, A. M. (2014). The effect of some genetic and nongenetic factors on fertility and growth traits in Awassi sheep. The Iraqi J. Agric. Sci. 45: 205211.

[11] Al-Rawi, A. A., Badawi, F. S., Said, A. S. I., Faraj, M. S. (1982). Genetic and phenotypic Parameter estimates for growth traits in awassi sheep. (Abst.) Proceeding American Society Animal Science Meeting, 38: 35.

[12] Al-Salman, M. H. (2009). Some factors influencing growth of Awassi lambs and their crosses from birth till weaning and weight at the age of 6 months, Al-Anbar J. Agric. Sci., 7: 128136.

[13] Al-Wahab, R. M. H. (2003). Effects of crossing Finnrams with Awassi sheep on prolificacy and other quantitative traits, J. Bio. Sci., 3: 32-42.

[14] Aziz, D. A. (1977). Genetic, non-genetic parameters of some traits in Awassi sheep. MS. Thesis, College of Agriculture, Forestry, Univ. of Mosul (In Arabic).

[15] Dikmen, S., Turkmen, I. I., Üstüner, H., Alpay, F., Balcı, F., Petek, M., Ogan, M. M. (2007). Effect of weaning system on lamb growth and commercial milk production of Awassi dairy sheep. Czech J. Anim. Sci., 52: 70-76. 
[16] Dzakuma, J. M., Nielsen, M. K., Doane, T. H. (1978). Genetic and phenotypic parameters of lamb weight. (Abst.) Proceeding American Society Animal Science Meeting, 45: 16.

[17] ElWakil, S. L., ElSayed, M., Ahmed, A. M., Sadek, R. R., Nigm, A. A. (2009). Genetic and phenotypic parameters of birth, weaning and yearling body weights of Barki sheep raised in the North West coast of Egypt. Egyptian J. Anim. Prod., 46: 43-52.

[18] Esenbuğa, N., Dayığlu, H. (2002). Effects of some environmental factors on growth traits of Awassi and Redkaraman lambs. Turk. J. Vet. Anim. Sci., 26: 145-150.

[19] Ghoneim, K. E., Shrode, R. R., Abdallah, R. K. (1982). Statistical analysis of birth weight in Awassi sheep in northern Iraq. Proceedings of the Sixth International Conference on Animal and Poultry Production held at University of Zagazig, Zagazig, Egypt, 21-23 September. 2: 488-496.

[20] Gursoy, O., Kirk, K., Cebeci, Z., Pollot, G. E. (1995). Genetic evaluation of growth performance in Awassi sheep. In: Gabiña D. (ed.) Strategies for sheep and goat breeding; Zaragoza: CIHEAM, p. 193-201. (Cahiers Options Méditerranéennes; $n$. 11). Meeting of the joint FAO/CIHEAM Network on Sheep and Goats, Subnetwork on Animal Resources, 1995/03/26-28, Sidi-Thabet http://om.ciheam.org/om/pdf/c11/96605556.pdf

(Tunisia)

[21] Hassen, Y., Sölkner, J., Fuerst-Waltl, B. (2004). Body weight of Awassi and indigenous Ethiopian sheep and their crosses. Small Rum. Res., 55: 51-56.

[22] Jawasreh, K. I. Z., Khasawneh, A. Z. (2007). Studies of some economic characteristic on Awassi lambs in Jordan. Egyptian J. of Sheep and Goats Sciences, 2: 76-85.

[23] Kamber, F. H. (1987). Studies on some factors affecting milk production and growth of lambs from birth to weaning in Awassi sheep. MS. Thesis, College of Agriculture, Forestry, Univ. of Mosul (In Arabic).

[24] Khalaf, A. I., Said, S. I., Edriss, S. M. (2010). Role of some genetic and environmental factors in growth traits of Turkish Awassi, local and crossbred lambs. The Iraqi J. Agric. Sci., 41: $12-22$.

[25] Kingwell, R. S., Abdil-Ghadim, K. A. (1995). Robinson, A. D.: Introducing Awassi sheep to Australia: an application of farming system models. Agric. Systems., 47: 451-471.

[26] Kridli, R. T., Abdullah, A. Y., Shaker, M. M., Al-Smadi, N. M. (2007). Reproductive performance and milk yield in Awassi ewes following crossbreeding. Small Rum. Res., 71: 103-108.
[27] Kazzal, N. T. (1973). Evaliuation of some genetic and environmental factors affecting growth and development of Awassi. Ph. D. Dissertation, Univ. Tennessee, Knoxville, Tennessee, USA.

[28] Kř́žžek J., Louda F., Jakubec V., Řeháček E. (1983): Genetické a negenetické factory ovlivnuující mateřské vlastnosti ovcí. Živoč. Výr. 28, 63-68.

[29] Lightfoot, J. (1988). The Awassi fat tail sheep. J. Agric., Western Australia., 28: 107-113.

[30] Obaido, M. (2010). Characterization and comparative evaluation of sheep production under traditional and improved management conditions of central Syria: MSc Thesis, Dep. of Anim. Sci. Çukurova University. Turkey.

[31] Özcan, M., Altinel, A., Yilmaz, A., Güneş, H. (2001). Studies on the Possibility of Improving Lamb Production by Two-way and Three-way Crossbreeding with German Black-Headed Mutton, Kivircik and Chios Sheep Breeds 1. Fertility, Lamb Survival and Growth of Lambs. Turk. J. Vet. Anim. Sci., 25: 687-694.

[32] SAS, (2010). Statistical Analysis System. Version 9.1, SAS Institute Inc., Cary NC, USA.

[33] Shaker, M. M., Abdullah, A. Y., Kridli, R., Šáda, I., Sovjak, R., Muwalla, M. M. (2002). Effect of crossing indigenous Awassi sheep breed with mutton and prolific sire breeds on the growth performance of lambs in a subtropical region. Czech J. Anim. Sci., 47: 239-246.

[34] Sunderman, F., Johns, M. (1994). Awassi fat tail- a chance for premium export. J. Agric., Western Australia., 35: 99-105.

[35] Tabbaa, M. J., Alnimer, M. A., Shboul, M., Titi, H. H. (2008). Reproductive characteristics of Awassi ewes mated artificially or naturally to Jordanian or Syrian Awassi rams. Anim. Reprod., 5: 23-29.

[36] Thrift, F. A., Whiteman, J. V., Kratzer, D. D. (1973). Genetic analysis of preweaning and postweaning lamb growth traits. J. Anim. Sci., 36: 640-643.

[37] Todorovski, N. (1988). The improved Awassi breed of sheep is wholly acclimatized to the natural conditions of MacedoniaYugoslavia. Proceedings of the Third World Congress on Sheep and Beef Cattle Breeding, Paris, France, 2: 739-742.

[38] Üstüner, H., Oğan, M. M. (2013). Main productive performance of Awassi sheep in the Central Anatolian Region of Turkey. Turk. J. Vet. Anim. Sci., 37: 271-276. 